\title{
Schmidt Laura
}

\section{Helyénvaló-e a helyreállító igazságszolgáltatás alkalmazása a szexuális jellegü büncselekmények esetében?}

\author{
Is it appropriate to use restorative justice \\ in cases of sexual offences?
}

\begin{abstract}
Absztrakt
A helyreállító igazságszolgáltatás során a hangsúly a büncselekmény által okozott sérelmeken és nem az elkövető büntetésén van (Zehr, 2005). Az érintett felek közötti párbeszéd kialakításával a sértett is meghatározó szerepet kap abban, hogy kifejezhesse igényeit a büntetés-végrehajtás folyamata során.

A helyreállító igazságszolgáltatás módszerét leginkább a fiatalkorú elkövetők és a kisebb kaliberủ büncselekmények esetében alkalmazzák. Mindezt annak ellenére, hogy egyre több tanulmány olvasható arról, hogy a felnőttek által elkövetett és a legkomolyabb bủncselekmények azok, melyek során elsősorban a visszaesés megelőzése szempontjából a leghatásosabb és legfontosabb az elkövető és a sértett helyreállító igazságszolgáltatásba vonása, hiszen ezek azok a büncselekmények, melyek során a legkomolyabb károk születnek, amelyek helyreállításra szorulnak (Strang, Sherman, Mayo-Wilson, Woods \& Ariel, 2013; Sherman \& Strang, 2007; Joudo-Larsen, 2014). Ez a tanulmány azt a kérdéskört járja körül, hogy a helyreállító igazságszolgáltatás módszere alkalmazható-e, illetve milyen feltételekkel alkalmazható a szexuális jellegü büncselekmények esetében. Tárgyalásra kerül, hogy alkalmazása a büntető igazságszolgáltatás helyett vagy mellett a legmegfelelőbb, illetve, hogy miért akarnának egyáltalán a sértettek találkozni az elkövetőkkel. A cikk kitér a leggyakrabban felmerülö aggodalmakra is, valamint arra is, hogy hogyan tud mégis müködni a helyreállító igazságszolgáltatás a szexuális jellegü büncselekményeknél. A nehézségek és a kockázatok ellenére a szakirodalom alapos tanulmányozása után is az ötlik fel a sorok közül, hogy érdemes a helyreállító igazságszolgáltatás szakmájának szembenézni a kihívásokkal és a resztoratív módszerek lehetőségét
\end{abstract}


biztosítani a szexuális jellegü büncselekmények elkövetői és sértettjei számára. Mindezt természetesen a megfelelő szabályok betartásával, illetve a megfelelö mögöttes tudással és képesítéssel együtt, hiszen nagyon mély és egész életekre kiható károk és fájdalmak keletkeznek ezen büncselekmények következtében. Felvetődik a kérdés, hogy ahelyett, hogy arra keressük a választ, lehetséges-e a helyreállító igazságszolgáltatás a szexuális jellegü büncselekményeknél, inkább minden ügyet egyenként kellene megvizsgálni, hogy a felek készen állnak-e bármiféle kommunikációra egymással.

Kulcsszavak: helyreállító igazságszolgáltatás, resztoratív, szexuális büncselekmény

\begin{abstract}
Restorative justice puts the emphasis on the harm caused by the criminal offence and not on the punishment of the offender (Zehr, 2005). By allowing communication between the parties involved, the victim has the chance to express what they need during the criminal proceeding. Restorative justice is mostly used in cases of youth offenders and less serious crimes even though there are more and more studies that claim that restorative justice is more effective (mainly in terms of reducing reoffending) and important when it is used with adult offenders and in the most serious crimes (Strang et al., 2013; Sherman \& Strang, 2007; Joudo-Larsen, 2014). This is not surprising when we think about how much harm these crimes cause to people. This study explores the question whether restorative justice can be and under what conditions can be used in cases of sexual offences. It brings along the question whether restorative justice should be used instead of or in addition to the punitive criminal justice system and why victims would want to meet their offenders. The article discusses the most common concerns and how restorative justice can work in cases of sexual offences. When examining the literature in this topic, it seems that the professionals tend to come to the conclusion that despite the difficulties and risks, it is worth facing the challenges when it comes to providing restorative justice for offenders and victims of sexual offences. Naturally, this should only be done with the right rules in place and with the right knowledge and qualifications because these sexual offences result in very deep and lifelong harm and pain. Maybe instead of looking for the answer whether it is appropriate to use restorative justice in cases of sexual offences, we need to look at every single case individually and make sure that the involved parties are ready for some form of communication with each other.
\end{abstract}

Keywords: restorative justice, reparation, sexual offence 


\section{A helyreállító igazságszolgáltatás definíciója}

Magyarországon is egyre ismertebb a leginkább angolszász országokban népszerü helyreállító igazságszolgáltatás, vagy más néven resztoratív igazságszolgáltatás módszerének használata a rendészeti munkában. Tony Marshall nemzetközileg széleskörben elfogadott definíciója szerint a „,helyreállitó igazságszolgáltatás azon folyamat, amely során egy konkrét büncselekmény érintettjei együttesen állapodnak meg arról, hogyan kezeljék a büncselekmény következményeit és annak jövőre vonatkozó hatásait”" (Marshall, 1999). A helyreállító igazságszolgáltatás lényege, hogy ahelyett, hogy az elkövetö büntetésén lenne a hangsúly, a büncselekmény által okozott sérelmek vannak a középpontban azáltal, hogy az érintett felek között párbeszédet kezdeményez (Zehr, 2005). Zehr meghatározó gondolata volt, hogy a sértetteknek központi szerepe legyen az igazságszolgáltatásban, arra fókuszálva, hogy nekik milyen igényeik vannak a büntetés-végrehajtás folyamata során. A helyreállító igazságszolgáltatás nagyon fontos hatással van a felek mentális egészségére és jövőbeni viselkedésükre: csökkentheti a sértettek félelemérzetét, dühét, szorongását, valamint hozzájárulhat az elkövetők bünözői létbe való visszaesésének csökkenéséhez is (Strang \& Sherman, 2003). Sok tanulmány szerint a helyreállító igazságszolgáltatás mindazonáltal költséghatékony módszer is, mivel a visszaesés csökkentésével és így a bűnözői létforma megszünésével hozzá tud járulni a túlzsúfoltsággal küzdő börtönök miatt kialakult problémák csökkentéséhez (Sherman, Strang, Mayo-Wilson, Woods \& Ariel, 2015; Strang et al., 2013).

\section{A helyreállító igazságszolgáltatás jelenlegi alkalmazása}

Ebben a tanulmányban elsősorban az angolszász országokban alkalmazott helyreállító igazságszolgáltatás módszerei kerülnek bemutatásra, illetve ezeknek a módszereknek a Magyarországon való megvalósításának lehetőségei. A világ számos pontján sokat fejlődött a helyreállító igazságszolgáltatás intézménye az elmúlt két-három évtizedben, és ez a változás nem csak azokban az országokban figyelhető meg, ahol jó szociális ellátórendszer müködik (Zinsstag, 2017). Ez a fejlődés leginkább a fiatalkorú elkövetők és a kisebb kaliberü bűncselekmények egyre szélesebb körü bevonásánál vehető szemügyre, hiszen még mindig rengeteg kétség merül fel politikai és esetenként szakmai oldalról is az erőszakosabb és súlyosabb ügyek resztoratív módszerekkel való kezelése kapcsán. Ennek ellenére egyre több tanulmány olvasható, melyek arról írnak, hogy a felnőttek által elkövetett és a legkomolyabb büncselekmények azok, melyek során 
a leghatásosabb (elsősorban a visszaesés megelőzése szempontjából) és a legfontosabb az elkövető és a sértett helyreállító igazságszolgáltatásba vonása, mivel ezek a büncselekmények okozzák a legkomolyabb károkat, melyek helyreállításra szorulnak (Strang et al., 2013; Sherman \& Strang, 2007; Joudo-Larsen, 2014).

A legismertebb resztoratív módszer az, amikor az elkövető és a sértett személyesen találkoznak, hogy facilitátorok (a facilitátor az a képzett személy, akinek a feladata a felek felkészítése és támogatása a folyamat során) segítségével közösen beszéljék meg az elkövetett büncselekmény következményeinek hatásait, illetve, hogy hogyan tudnák az okozott károkat helyreállítani, így segítve is egymáson (részletesebb leíráshoz lásd Liebmann, 2007). Ez a módszer kiegészülhet úgy, hogy ezen a személyes találkozón részt vesznek segítő szakemberek, az elkövető vagy a sértett támogatói (barátok, családtagok), illetve akár a közösség különböző képviselői is. Az elkövető és a sértett között létrejöhet indirekt kommunikáció is, amikor személyesen nem találkoznak, de a facilitátoron keresztül beszélnek egymással levél, illetve üzenetek formájában. A felek között bármiféle kommunikáció csak akkor jöhet létre, ha mind az elkövető, mind a sértett önkéntesen szeretne részt venni a folyamatban, és amint valaki meggondolja magát, a folyamatot le kell zárni. A folyamat során a facilitátorok részéről nélkülözhetetlen még szem előtt tartani, hogy a felek egyenjogúságára törekedjenek. Ahhoz, hogy a folyamatból haszna legyen minden félnek, elengedhetetlen, hogy tisztelettel meghallgassák a másikat és betartsák a facilitátor által közölt szabályokat, alapelveket. Jelenleg számos országban alkalmazzák a helyreállító igazságszolgáltatás módszereit (ilyen például Norvégia, Kanada, Egyesült Államok, Egyesült Királyság, Új-Zéland, Ausztrália), és több kutatás, illetve tanulmány is született ezen a szakterületen (például Sherman \& Strang, 2007; Jülich, Buttle, Cummins \& Freeborn, 2010; Daly \& Stubbs, 2006).

Az Európai Bizottság az Európai Parlament és a Tanács elé terjesztett 2020. májusi jelentése szerint a tagállamoknak nem kötelező a helyreállító igazságszolgáltatás módszerének alkalmazása, azonban jelenleg 24 tagállamban müködik ez az intézmény (URL1). Magyarországon a mediáció és a helyreállító igazságszolgáltatás intézménye ugyanazt jelenti, azonban elsősorban a mediáció fogalmával találkozhatunk. A jelenlegi jogszabályi környezet és az alkalmazott igazságszolgáltatási gyakorlat mellett a mediáció alkalmazásának lehetősége fennáll hazánkban, ezen belül a büntetö- és szabálysértési ügyekben ezt a folyamatot közvetítői eljárásnak hívják. A közvetítői eljárás a szabálysértések és a kevésbé súlyos büncselekmények elkövetöivel szemben egyfajta alternatívaként szolgál, így próbálva csökkenteni a büntető igazságszolgáltatás terheit, azonban 2018 óta súlyosabb büncselekmények esetében is alkalmazható ez a módszer. A büntetöügyekben és szabálysértési ügyekben alkalmazható közvetítöi 
eljárás rendelkezéseit a 2006. évi CXXIII. törvény, illetve a 2012. évi II. törvény (67/A. A közvetítői eljárás általános szabályairól szóló rész) szabályozza.

\section{A helyreállító igazságszolgáltatás alkalmazása szexuális jellegú büncselekmények esetében}

Sok tanulmány foglalkozik azzal a kérdéskörrel, hogy mely ügyek esetében a legalkalmasabb a helyreállító igazságszolgáltatás módszerének alkalmazása, hogyan érhetjük el a legjobb eredményeket, a visszaesés csökkenését és a sértettek elégedettségének növekedését (például Sherman \& Strang, 2007; Sherman et al., 2015; McGlynn, Westmarland \& Godden, 2012). Az egyik megosztó kérdéskör, hogy a szexuális jellegủ büncselekmények elkövetése után helyénvaló-e alkalmazni a helyreállító igazságszolgáltatás módszereit. Vajon ez okozhat-e újabb károkat a sértettnek? Kockáztatjuk-e annak a veszélyét, hogy a sértett reviktimizálódik, újra sértetté válik a folyamat során, és újra előtörnek belöle azok a negatív érzések, melyek a büncselekmények következtében alakultak ki? Sok ilyen és ehhez hasonló kérdés merül fel ebben a témakörben és jelen tanulmány néhány kutatás, esettanulmány ismertetésével igyekszik bemutatni a szakma témához való hozzáállását. Fontos megállapítani, hogy pontosan mit értünk a szexuális jellegü büncselekmények alatt. A Büntető Törvénykönyvről szóló 2012. évi C. törvény (Btk.) XIX. fejezete foglalkozik a „nemi élet szabadsága és a nemi erkölcs elleni" büncselekményekkel. A Btk. az alábbi tényállásokat rögzíti szexuális büncselekményként: szexuális kényszerítés (196. §), szexuális erőszak (197. §), szexuális visszaélés (198. §), vérfertőzés (199. §), kerítés (200. §), prostitúció elősegítése (201. §), kitartottság (202. §), gyermekprostitúció kihasználása (203. §), gyermekpornográfia (204. §), szeméremsértés (205. §). Az Egységes Nyomozóhatósági és Ügyészségi Bünügyi Statisztika (ENyÜBS) a Belügyminisztérium és a Legfőbb Ügyészség közös adatgyüjtése. Az ENyÜBS adatai alapján 2018. július hónaptól az utolsó módosítás dátumáig, 2020. november 3-ig tartó időszakban az adott tényállások regisztrált büncselekmény szerinti hazai megoszlása a következő: szexuális kényszerítés: 177 eset; szexuális erőszak: 666 eset; szexuális visszaélés: 205 eset; vérfertőzés: 16 eset; kerítés: 96 eset; prostitúció elősegítése: 41 eset; kitartottság: 42 eset; gyermekprostitúció kihasználása: 54 eset; gyermekpornográfia: 521 eset; szeméremsértés: 951 eset (URL2).

A szexuális jellegü büncselekmények sértettjeinél olyan fizikai és pszichológiai tünetek jelentkezhetnek, melyek kezelés nélkül akár komoly pszichiátriai szövődményekké is alakulhatnak. Sok esetben megfigyelhető a büncselekményhez 
társított erős szégyenérzet, mely következményeként a sértett nem mer beszélni az általa átéltekről. Továbbá manapság még mindig jelen van a társadalomban az áldozathibáztatás, mely során a sértett ruházatát, viselkedését tartják a büncselekmény kiváltó okának, ezzel azt üzenve, hogy ha a sértett jobban odafigyel, máshogy öltözködik, máshogy viselkedik, akkor elkerülhető lett volna a büncselekmény. Megfigyelhető még az úgynevezett „,ideális” sértett iránti igény jelensége is. Igény egy olyan sértettre, aki az elvárásoknak megfelelően reagál a rendőrségen, a tárgyaláson, mindig a cselekménynek megfelelő reakciókat, érzelmeket produkálja, mert, ha nem, akkor valószínű hazudik a történtekről, hiteltelen a vallomása. A szexuális jellegü büncselekmények sértettjeinek azonban sokféle reakciója, tünete lehet, mely nem feltétlenül illik bele ebbe a narratívába, hiszen nem mindenki fog ugyanúgy reagálni egy ilyen traumatikus esemény következtében. Így nem meglepö, hogy sok sértett nem jelenti a bủncselekményt a rendőrségen, ez sosem vagy csak évekkel később jut a hatóság tudomására, amikor már nem feltétlenül tudnak olyan hatékonyan fellépni, mint a büncselekmény utáni napokban, hetekben (Department of Economic and Social Affairs, 2015).

\section{A büntető igazságszolgáltatás helyett vagy mellett?}

A statisztikák azt mutatják, hogy a szexuális büncselekmények nagyon kis százaléka jut a rendőrség tudomására, sok országban (például Skócia, Jordánia, Grúzia, Fülöp-szigetek) ez a szám 10\% alatt van (Zinsstag, 2017; Department of Economic and Social Affairs, 2015). Ezeknek az eseteknek még kisebb százaléka, ami bíróságra kerül. Ebben az esetben pedig a sértettnek egy újabb kellemetlen élményt kell elviselnie, az események újbóli átélése és az ügyvédek által feltett igen személyes, intim kérdések formájában is. A büntető igazságszolgáltatás rendszerének javítása mellett a helyreállító igazságszolgáltatás intézménye szerepet játszhat abban, hogy a sértettnek olyan lehetőségeket nyújtson, melyeket a bírósági tárgyalás során nem kapna meg. Az angolszász modell szerint a helyreállító igazságszolgáltatás a büntetőeljárás során bármikor megkezdődhet, de egy olyan ügyben is lefolyhat, mely soha nem lett jelentve a rendőrségnek, így azoknak a sértetteknek is van lehetősége egyfajta igazságszolgáltatásban részesülni, akik valamilyen okból kifolyólag nem akarnak vagy már nincs lehetőségük a hatóságokhoz fordulni. Ez a modell ebben a formában nem tudna müködni a magyar jogrendszerben, megvalósíthatóságának feltétele lenne a megfelelő jogi keretek kialakítása. Sok esetben a sértettek évekkel a szexuális büncselekmény megtörténte után érzik úgy, hogy szeretnének találkozni 
az elkövetővel és feltenni olyan kérdéseket, mint, hogy miért történt a büncselekmény, miért ők lettek kiválasztva vagy akár, hogy mit csinál az elkövető most és abbahagyta-e a bünözést (Zinsstag, 2017). Néhány feminista csoport azzal érvelve ellenzi a szexuális jellegü büncselekmények esetében alkalmazott helyreállító igazságszolgáltatást, hogy ha a büntető igazságszolgáltatás helyett használjuk, azzal rengeteg kárt okozhatunk, hiszen sok éven át kellett küzdeni azért, hogy néhány szexuális jellegü büncselekmény egyáltalán büncselekménynek számítson és bírósági ügy lehessen belőle (Daly \& Stubbs, 2006).

Egy Angliában végzett tanulmány szerzői online kérdőívet fejlesztettek ki, hogy felmérjék 131 ember attitüdjét a szexuális jellegü büncselekmények esetében alkalmazott helyreállító igazságszolgáltatás vonatkozásában (Marsh \& Wager, 2015). Természetesen a minta nagysága miatt fenntartásokkal kell kezelni az eredményeket, azonban a téma érzékenysége okán sok esetben csak kis mintájú kutatásokkal lehet találkozni. A megkérdezettek közül 40-en nyilatkozták, hogy legalább egyszer sértettjei voltak valamiféle szexuális viktimizációnak. Közülük volt, aki jelentette az esetet a hatóságoknak, de olyan is volt, aki nem. Érdekes eredmény, hogy az összes válaszadó $81 \%$-a nyilatkozott úgy, hogy jó ötletnek tartja, ha a sértett és az elkövető személyesen tud találkozni egy resztoratív konferencia keretében szexuális jellegü büncselekmények elkövetése után. A magukat sértettnek vallók 56\%-a a helyreállító igazságszolgáltatást a büntető igazságszolgáltatás rendszere mellett képzeli el, míg 30\%-uk a büntető igazságszolgáltatás alternatívájaként. Fontos megjegyezni, hogy azok, akik alternatívaként preferálnák ezt a folyamatot, azok a megkérdezettek voltak, akik nem jelentették a velük megtörtént esetet a hatóságoknak.

\section{Miért akarnának a sértettek találkozni az elkövetőkkel?}

Keenan (2018) kiemeli annak fontosságát, hogy a helyreállító igazságszolgáltatás a szexuális büncselekmények - ugyanúgy, mint más büncselekmények esetében is mind az elkövető, mind a sértett önkéntes beleegyezése esetén jöhet csak létre. Egyik fél sem lehet belekényszerítve abba a döntésbe, hogy a sértett vagy a sértő oldallal kapcsolatba lépjen az akarata ellenére, hiszen ezzel nemcsak a módszer pozitív hatásait szüntetjük meg, hanem az így létrejött kapcsolatnak kifejezetten negatív és káros hatásai is lehetnek mindkét fél számára. Sokan értetlenül állnak az előtt, hogy egy sértett miért akarna találkozni az elkövetővel egy ilyen traumatikus büncselekmény elkövetése után. A gyakorlat azt mutatja, hogy a szexuális büncselekmények sértettjei ugyanazon okokból kifolyólag szeretnének a helyreállító igazságszolgáltatás módszereivel élni, 
mint a nem szexuális büncselekmények sértettjei (Keenan, 2018). Az egyik ilyen leggyakoribb ok, hogy lehetőség legyen a sértett számára, hogy megoszsza az elkövetővel a gondolatait, kifejezze, hogy a trauma és a büncselekmény következményei miként hatnak a mindennapi életére. A sértettek a helyreállító igazságszolgáltatás során lehetőséget kapnak arra, hogy megszakítás nélkül, a saját szavaikkal meséljék el a történteket és a büncselekmény következményeinek életükre mért hatásait (Marsh \& Wager, 2015). Ez a lehetőség a büntető igazságszolgáltatás rendszerében sokszor nem adatik meg a sértetteknek, pedig igényük lenne rá. Néhány sértett azt szeretné demonstrálni, hogy mennyire reziliens még egy ilyen esemény bekövetkezése után is (Keenan, 2018). Amit pedig szinte minden esetben hallani, hogy kérdéseket szeretnének feltenni és válaszokat kapni az elkövetőtől, illetve azt kívánják elérni, hogy az elkövető felelősséget vállaljon a tetteiért. Továbbá a sértettek számára a helyreállító igazságszolgáltatás lehetőséget adhat arra, hogy visszavegyék azt a kontrollt, amit korábban az elkövető elvett tölük, és hogy döntéseket hozhassanak a folyamat során, amely a bírósági tárgyalás alatt nem adatik meg számukra (McGlynn et al., 2012). Arról sem feledkezhetünk meg, hogy már maga az előkészítés és a felkészítés folyamata nagyon hasznos lehet egy sértettnek, még akkor is, ha a folyamat nem jut el a személyes találkozóig (Jülich et al., 2010). Az előkészítés és a felkészítés során a sértett többször találkozik a facilitátorral, beszélhet vele az érzéseiről, a szükségleteiről, és a facilitátor célzott segítségnyújtás céljából továbbküldheti a sértettet más segítő szakemberek felé.

\section{A helyreállító igazságszolgáltatás alkalmazásával kapcsolatos aggodalmak}

Az egyik aggodalom azzal szemben, hogy miért ne alkalmazzák a helyreállító igazságszolgáltatás módszereit szexuális jellegü büncselekmények elkövetése után az, hogy a facilitátorok eléggé képzettek-e ilyen komplex ügyek levezetésére, tisztában vannak-e a folyamat során fellépő esetleges veszélyekkel. Keenan (2018) összefoglalója alapján elmondható, hogy azokban az országokban, ahol jelenleg alkalmazzák a helyreállító igazságszolgáltatás módszereit, országonként eltérő, hogy milyen képzést kapnak a szexuális bűncselekményekkel foglalkozó szakemberek. Néhány országban a facilitátorok kapnak képzést a helyreállító igazságszolgáltatásban, de nem kapnak képzést külön a szexuális büncselekményekről (például Hollandia), más országokban pont ennek a fordítottja az igaz (például Belgium), de természetesen az is elöfordul, hogy van képzés mindkét területre vonatkozóan (például Norvégia). 
Azonban egységesnek tủnik az eljárást alkalmazó országokban, hogy ezeknél a komplex ügyeknél csak olyan facilitátorokat foglalkoztatnak, akik tapasztalt szakemberek, akár olyan pszichológiai, pszichoterápiai hátérrel, mely nagyban segíti a munkájukat. Keenan (2018) szakmai véleménye, hogy szükség lenne a már meglévő alap helyreállító igazságszolgáltatás képzés mellé egy speciális képzésre is azon szakemberek részére, akik szexuális büncselekményekkel fognak foglalkozni, mind az ezekre a büncselekményekre jellemző hatalmi kiegyensúlyozatlanság, mind magának a büncselekménytípusnak a komplexitása miatt. A szakemberek így remélhetőleg könnyebben felismerik a reviktimizáció (újbóli sértetté válás, de már nem a büncselekmény, hanem az utána következő folyamat eredményeként, például áldozathibáztatás miatt), a retraumatizáció (újbóli átélése a traumának valamilyen kiváltó ok hatására, például a büncselekmény újbóli felidézése okán) és a már említett hatalmi kiegyensúlyozatlanság jeleit, és adekvát módon tudják is kezelni ezeket a folyamat során. A speciális tréning szükségessége elsősorban abban rejlik, hogy a szakemberek tisztában legyenek a szexuális büncselekmények traumáinak és hatásainak rendkívül összetett jellegzetességeivel (Keenan, 2018; Vives-Cases, Ruiz-Cantero, Escribà-Agüir, \& Miralles, 2011; Petrak \& Hedge, 2002). A büncselekmény következményeként a sértettnél poszttraumás stressz szindróma (PTSD) léphet fel, amely egy szorongásos zavar, ami egy pszichológiailag traumatikus esemény után jelentkezik elöször. Olyan tünetek jelentkezhetnek, mint például a trauma állandó újraélése az emlékek akaratlan előidézésével vagy akár egy illat hatására; alvászavar; koncentrációs zavar; depresszió. Ezek a tünetek kezelés nélkül sokszor a mértéktelen alkohol-, illetve kábítószerfogyasztáshoz vezethetnek, illetve egyéb pszichiátriai kórképek is kialakulhatnak.

Az ilyen típusú ügyek nehézségei között említhetők még, hogy az elkövető sok esetben ismert a sértett számára, akár egy közeli családtag vagy barát személyében; a sértett sokszor magát hibáztatja a történtekért; az elkövetőknél elöfordulhat, hogy megpróbálják megindokolni a büncselekményt és a felelősség legalább egy részét a sértettre áthárítani. A szakembereknek nagy felelőssége van abban, hogy tudatában legyenek ezeknek a potenciális veszélyforrásoknak és adekvátan tudják kezelni ezen helyzeteket. Fontos az is, hogy a szakemberek ismerjék a helyi lehetőségeket, mind abban az esetben, ha az elkövetö terápiás lehetőségeit nézzük, mind akkor, ha a sértett kíván terápiában részt venni (Keenan, 2018). Ez akkor is kiemelten fontos, hogy ha a folyamat nem jut el az elkövető és a sértett közti kommunikáció fázisáig, de valamelyik fél további pszichikai segítése viszont szükséges marad. A laikusok sokszor azt gondolják, úgy általában a helyreállító igazságszolgáltatás intézményéről, hogy ha az elkövető részt vesz ebben a folyamatban, azzal „megússza” a büntetését, és hogy 
ez egy könnyű alternatíva minden máshoz képest. Azonban szembenézni azzal az emberrel, aki ellen egy büncselekményt elkövettél, felelősséget vállalni a tetteidért és kitenni magad annak, hogy bármilyen kérdést feltegyen neked a sértett, semmiképp sem mondható egy könnyü folyamatnak. Mind a sértett, mind az elkövető részéről nagy lelkierő és nem utolsó sorban bátorság kell ahhoz, hogy egy közös folyamatban részt vegyenek és szembe merjenek nézni egymással, valószínüleg a büncselekmény elkövetése óta először. Természetesen előfordulnak olyan esetek, amikor a felek háttérben meghúzódó motivációi nem őszinték, akár az elkövető antiszociális személyiségzavara, akár a sértett bosszúvágya okán, és manipulációval próbálják meg érvényesíteni az akaratukat. Ezekben az esetekben mutatkozik meg igazán az előkészítés és a facilitátorok ilyen helyzetek és lehetőségek előfordulására való felkészítésének fontossága. Ez az aggodalom egy fontos érv lehet amellett, hogy miért kell pszichológiai, pszichoterápiai háttérrel rendelkeznie azoknak a facilitátoroknak, akik komplex ügyek helyreállító igazságszolgáltatásban való lebonyolítását végzik.

\section{Hogyan tud mégis működni?}

Az elmúlt években leginkább az Egyesült Államokból olvashattunk olyan híreket, melyek a felsőoktatási intézmények kampuszain történt szexuális büncselekményekről szólnak, azonban Magyarországon is nagy hírt keltett 2014ben az ELTE egyik gólyatáborában egy diák ellen elkövetett szexuális erőszak botránya. Sok olyan egyesült államokbeli esetről lehetett hallani, mely során az intézmény, melynek területén történt a büncselekmény, nem intézkedett megfelelően és próbálták minél nagyobb csendben eltussolni az esetet. A sértettek így nagyon sokszor nem kaptak megfelelő támogatást, illetve az igazságszolgáltatás is elmaradt. Koss, Wilgus és Williamsen (2014) tanulmánya azt a lehetöséget járja körül, hogyan lehetne a helyreállító igazságszolgáltatás módszereit alkalmazni ezekben az ügyekben, amely így nagyobb mértékben hozzájárulna a felek által megélt sérelmek kezeléséhez, mint a jelenleg érvényben lévő igazságszolgáltatás módszere. Koss és társai (2014) négy lehetőséget sorolnak fel arra vonatkozóan, hogy a helyreállító igazságszolgáltatás hol tud bekapcsolódni a károk helyreállításának folyamatába a felsőoktatási intézmények diákjai által átélt szexuális jellegü büncselekmények megtörténte után. Az első lehetőség a büntető igazságszolgáltatás helyett történő helyreállító igazságszolgáltatás, mely során mindkét fél önkéntesen egyezik bele abba, hogy valamiféle kommunikáció, leginkább egy személyes találkozó során beszéljék meg a történteket. Egy másik lehetőség akkor adódik, ha a nyomozás során úgy találják, 
hogy a gyanúsított nem követett el büncselekményt, viszont mind a sértett, mind a gyanúsított szeretné személyesen megbeszélni a történteket, és a gyanúsított is elismeri, hogy felelőssége van a károk keletkezésében. A harmadik lehetőség, amikor a gyanúsítottat bünösnek találják és a két fél közösen, akár a tágabb közösség bevonásával szeretné megbeszélni a büntetés feltételeit (például a felsöoktatási intézményből való ideiglenes távolmaradás vagy az intézményből való kirúgás lehetőségeit). A negyedik lehetőség pedig egyfajta reintegrációs célt szolgál, ha mondjuk egy diákot bünösnek találnak és felfüggesztik egy időre a felsőoktatási intézményből, azt követően, hogy lejár a felfüggesztése, önkéntes alapon szervezhetnek egy olyan resztoratív kört, amelyben a közösség és különbözö támogató szakemberek segíthetik a könnyebb visszailleszkedést. Ennek a tanulmánynak a szerzői úgy ítélik, hogy ezek a beavatkozási pontok mind valamilyen pozitív hatással szolgálnának a felek számára, és sokkal inkább személyre szabott ez az eljárásmód és esetleges megegyezés, amely a helyreállító igazságszolgáltatás folyamata során kialakul.

Egy másik tanulmány online felmérése szerint, melyben a megkérdezettek között szexuális jellegü bủncselekmények sértettjei is szerepeltek, három csoportra lehetett osztani a sértettek válaszát arra a kérdésre, hogy milyen szükségleteik vannak és milyen támogatásra lenne szükségük a helyreállító igazságszolgáltatás folyamata során (Marsh \& Wager, 2015). A három legfontosabb területként az egyénre szabott támogatást (például terápia), a megfelelő előkészítést/ felkészítést és a biztonságot nevezték meg. Volt, aki azt javasolta, hogy azok a sértettek, akik már végigmentek a helyreállító igazságszolgáltatás folyamatán egyfajta tanácsadást tarthatnának olyan sértetteknek, akik azon gondolkoznak, hogy részt vesznek a folyamatban, de kérdéseik és fenntartásaik vannak.

McGlynn, Downes \& Westmarland (2017) egy kutatás során húsz olyan nőt kérdeztek meg az igazságosság feltételeiről, akik saját bevallásuk szerint valamiféle szexuális büncselekmény sértettjei voltak legalább egyszer életükben. A megkérdezettek válaszaiból három olyan téma rajzolódik ki, amely az igazságérzetükhöz nagyban hozzájárul: az elismerés, a hangadás és az értelmes következmények. Az elismerés fogalma alatt a sértettek a büncselekmény megtörténtének és az átélt események jelentőségének elismerését értették, mely véleményük szerint elengedhetetlen ahhoz, hogy igazságosnak érezzék az igazságszolgáltatás folyamatát. A helyreállító igazságszolgáltatás folyamatának megkezdéséhez nélkülözhetetlen, hogy az elkövető felelösséget vállaljon a büncselekmény elkövetéséért, illetve a sértettet ért károkért, így a resztoratív módszerek már teljesítik a sértettek igazságosságérzetének feltételét. Ez sok esetben szemben áll a büntető igazságszolgáltatás intézményével, amely során jellemzően nem fordul elö, hogy bünösnek vallják magukat az elkövetők. A hangadás fogalma 
úgy értelmezhető, mint a sértettek által átélt történéseknek és érzéseknek saját szavaikkal való, megszakítás nélküli megosztása. Ez az elem a helyreállító igazságszolgáltatás folyamata során megvalósul, hiszen mind a két félnek van lehetősége megszakítás nélkül elmondani, amit szeretnének, mielőtt a közös beszélgetés stációjába érnének. Egy bírósági tárgyalás során ez nem egészen így történik, ott a felek kérdésekre válaszolnak és nem is arról beszélnek, amiről ők szeretnének, hanem leginkább az események tárgyilagos rekonstrukciója történik. A sértettek az értelmes következményeket hozták fel harmadik fontos elemként, mint ami az igazságérzet eléréséhez járul hozzá. Ez alatt azt kell érteni, hogy az elkövető büntetésének van visszatartó ereje és hozzájárul a viszszaesés csökkentéséhez. Volt olyan sértett, aki megemlítette a börtönbüntetés szükségességét az elkövetők számára, azonban aggodalmát is kifejezte azzal kapcsolatban, hogy nincs elég kezdeményezés a rácsokon belüli reintegráció lehetőségeire, hiszen a lényeg az kellene legyen, hogy valaki a szabadulás után egy jobb és másféle gondolkodású emberként távozzon a büntetés-végrehajtási intézményből. A helyreállító igazságszolgáltatás során az egyik cél, hogy az elkövetö lássa a sértetten saját tetteinek következményeit és hallja a sértett szavaival, hogy miken ment keresztül a büncselekmény során és azt követően, így járulva hozzá, hogy az elkövető tudatosan szembesüljön tetteinek hatásaival.

\section{Milyen előnyökkel járhat a helyreállító igazságszolgáltatás a sértett és az elkövető számára?}

Talán a legmeggyőzőbb bizonyíték a helyreállító igazságszolgáltatás alkalmazása mellet vagy ellen az, ha meghallgatjuk azoknak a sértetteknek és elkövetöknek a tapasztalait, akik már részt vettek a folyamatban. A tapasztalat azt mutatja, hogy azzal, hogy a sértettnek lehetősége van az előkészítés, felkészítés során beszélnie a vele történtekről, ez erőt ad neki, hogy őszinte lehessen a folyamat során (Goldsmith, Halsey \& Bamford, 2005). Ahogy gyakran más büncselekmények sértettjeinél, úgy a szexuális jellegü büncselekmények sértettjeinél is előfordulhat, akár az őket ért áldozathibáztatás okán, hogy önmagukat hibáztatják a történtekért, azon gondolkoznak, hogy mit tudtak volna másképp tenni. A sértettek beszámolói alapján azonban az elkövetövel való kommunikáció, a kérdéseikre kapott válaszok sokszor azt a hatást érik el, hogy a sértett nem hibáztatja magát többet a történtekért, a büncselekményért való felelősség teljes egészében visszakerül az elkövetőre (Naylor, 2010; Koss \& Achilles, 2008). A sértettek sokszor azért szeretnének beszélni az elkövetővel, mert olyan kérdéseik vannak, melyekre csak ők tudnak válaszolni. 
Természetesen ekkor a facilitátornak fontos szerepe van abban, hogy felkészítse a sértettet arra, hogy a kérdésére nem fog választ kapni, illetve, hogy nem olyan választ kap, amit szeretne. Azonban a vizsgált tanulmányok alapján azt lehet mondani, hogy a sértettek többsége kap választ az eddig megválaszolatlan kérdéseikre, mely hozzájárul a folyamattal való elégedettségükhöz (Pali \& Madsen, 2011; Strang et al., 2006). A büncselekmény következményeként kialakult PTSD tünetek és a sértett félelemérzetének csökkenése is megfigyelhetö volt több esetben, mely során az elkövetővel való találkozás előtti és utáni értékeket hasonlították össze a kutatók (Koss, 2014; Strang et al., 2006).

A helyreállító igazságszolgáltatás folyamata a tapasztalatok alapján az elkövetők számára is sok előnnyel járhat. A folyamatba való belépéshez szükséges valamilyen szintủ felelősségvállalás, azonban ennek mértéke nagyban változhat pozitív irányba annak hatására, hogy az elkövető a sértett szájából hallja tetteinek hatását. Megfigyelhető a büncselekményért való teljes felelősségvállalás, annak a megértése, hogy tetteik milyen következményekkel jártak nemcsak a sértett, de a közvetlen és közvetett környezete számára is (Koss, 2014; Jülich et al., 2010; Goldsmith et al., 2005). Továbbá a folyamat végeztével mérhető az elkövető empátiájának növekedése, több esetben a megbánás megjelenése, valamint annak elősegítése, hogy az elkövető sikeresen vissza tudjon illeszkedni a saját családi környezetébe, mely fontos faktor a bünözői létbe való visszaesésnek a megelőzése során (Koss, 2014; Goldsmith et al., 2005; Jülich et al., 2011).

\section{Következtetések}

Van néhány nagyon fontos feltétele annak, hogy egy szexuális jellegü büncselekmény elkövetése után mindkét fél számára biztonságos módon lehessen bármiféle kommunikációt facilitálni elkövető és sértett között. Ezek közül a feltételek közül elengedhetetlen megemlíteni, hogy a felek önkéntes alapon egyeznek bele a helyreállító igazságszolgáltatásba, a facilitátorok képzett szakemberek, akik speciális tréninget kapnak a szexuális büncselekmények témakörében, illetve, hogy mind az elkövető, mind a sértett adekvát módon fel vannak készítve a folyamat részleteiröl. Fontos azt is belátni, hogy mindkét fél véleménye változhat a folyamatról annak megkezdése után, és biztosítani kell a lehetőséget, hogy bármelyik fél bármely szakasz során kiléphessen abból. Ehhez azonban nélkülözhetetlen, hogy a facilitátor az első találkozótól kezdve felkészítse a feleket az ilyen és ehhez hasonló helyzetekre, hogy minimalizálni tudja egy ilyen folyamat megszakításából adódó fájdalmakat, csalódottságot. Azoktól a helyreállító igazságszolgáltatás facilitátoroktól, akiknek az alapképzésen kívül 
nincsen a szexuális büncselekmények témájában elvégzett külön képesítésük, nem is várható el, hogy olyan tudással és képességekkel rendelkezzenek, melyek elengedhetetlenek egy szexuális büncselekmény után létrejött elkövető-sértett kommunikáció lebonyolítására (Keenan, 2018). Ennek fényében felmerül az igény ezen szakemberek továbbképzésére terápiás, etikai és jogi szempontból is. A nehézségek és a kockázatok ellenére azonban, a szakirodalom alapos tanulmányozása után is az ötlik fel a sorok közül, hogy érdemes a helyreállító igazságszolgáltatás szakmájának szembenézni a kihívásokkal, és a resztoratív módszerek lehetőségét biztosítani a szexuális jellegü büncselekmények elkövetői és sértettjei számára a megfelelő szabályok betartásával, illetve a megfelelő mögöttes tudással és képesítéssel együtt, hiszen nagyon mély és egész életekre kiható károk és fájdalmak keletkeznek ezen büncselekmények következtében. Talán nem azt a kérdést kellene feltennünk, hogy lehetséges-e a helyreállító igazságszolgáltatás a szexuális jellegü büncselekményeknél, hanem minden ügyet egyenként kellene megvizsgálni, hogy a felek készen állnak-e bármiféle kommunikációra egymással. A szexuális büncselekmények esetében alkalmazott helyreállító igazságszolgáltatás folyamatának megkezdése előtt szükséges lenne a sértettet és az elkövetőt segítő szakemberek számára egy megbeszélést szervezni, mely során a szakemberek közösen beszélik át a folyamat lépéseit és a felmerülö aggodalmakat (Robson, 2018). Hasznos lenne az ilyenfajta megbeszélést a folyamat során többször megismételni, illetve a sértett és elkövető közötti kommunikáció lezárását követően is, hogy a szakemberek átlássák, hogy a klienseiket ki hogyan tudja támogatni a folyamat végeztével. Véleményem szerint ezeknél az ügyeknél, a büncselekmény súlyossága okán, fontos, hogy ne egy, hanem kettő facilitátor együttesen dolgozzon a sértettel és az elkövetővel. Továbbá szükségszerü, hogy ezen facilitátorok számára biztosítva legyen a folyamatos szupervízió lehetősége, mely során egy náluk tapasztaltabb szakemberhez fordulhatnak segítségért, tanácsért. Ha esélyt sem adunk a folyamatban való részvételre azoknak a sértetteknek, akik szeretnének élni valamilyen resztoratív módszerrel, azzal mi döntünk helyettük, és csakúgy, mint a büncselekmény során, újra elvesszük tölük a döntés lehetöségét, mely rengeteg negatív következménnyel járhat. A helyreállító igazságszolgáltatás egyik nagy előnye, hogy a büncselekmény elkövetése utáni bármilyen szakaszban alkalmazható, attól függően, hogy a felek mikor érzik úgy, hogy készen állnak kommunikálni egymással. A szexuális jellegü büncselekmények tekintetében azoktól a sértettektől sem szabad elvenni ennek a módszernek a lehetőségét, akik több évvel az események után érzik csak kellően felkészülve magukat, de azoktól sem, akik bármilyen okból kifolyólag úgy döntöttek, hogy nem jelentik a büncselekményt a hatóságoknak. 


\section{Felhasznált irodalom}

Daly, K., \& Stubbs, J. (2006). Feminist engagement with restorative justice. Theoretical Criminology, 10(1), 9-28. https://doi.org/10.1177/1362480606059980

Department of Economic and Social Affairs (2015). The World's Women 2015. Trends and Statistics. United Nations.

Goldsmith, A., Halsey, M. \& Bamford, B. (2005). Adult Restorative Justice Conferencing Pilot: An Evaluation. South Australian Courts Administration Authority.

Joudo-Larsen, J. (2014). Restorative justice in the Australian criminal justice system. AIC reports. Australian Institute of Criminology.

Jülich, S., Buttle, J., Cummins, C., \& Freeborn, E. V. (2010). Project Restore: An exploratory study of restorative justice and sexual violence. AUT University.

Jülich, S., McGregor, K., Annan, J., Landon, F., McCarrison, D. \& McPhillips, K. (2011). Yes, There is Another Way! Canterbury Law Review 17, 222-228.

Keenan, M. (2018). Training for Restorative Justice Practice in Sexual Violence Cases. The International Journal of Restorative Justice, 1(2), 291-302. https://doi.org/10.5553/ IJRJ/258908912018001002007

Koss, M. \& Achilles, M. (2008). Restorative Justice Approaches to Sexual Violence. National Resource Center on Domestic Violence.

Koss, M. P. (2014). The RESTORE program of restorative justice for sex crimes: Vision, process, and outcomes. Journal of Interpersonal Violence, 29(9), 1623-1660. https://doi. org/10.1177/0886260513511537

Koss, M. P., Wilgus, J. K., \& Williamsen, K. M. (2014). Campus sexual misconduct: Restorative justice approaches to enhance compliance with Title IX guidance. Trauma, Violence, \& Abuse, 15(3), 242-257. https://doi.org/10.1177/1524838014521500

Liebmann, M. (2007). Restorative justice: How it works. Jessica Kingsley Publishers.

Marsh, F., \& Wager, N. M. (2015). Restorative justice in cases of sexual violence: Exploring the views of the public and survivors. Probation Journal, 62(4), 336-356. https://doi. org/10.1177/0264550515619571

Marshall, T. F. (1999). Restorative justice: An overview. Home Office.

McGlynn, C., Downes, J., \& Westmarland, N. (2017). Seeking justice for survivors of sexual violence: Recognition, voice and consequences. In Zinsstag, E. \& Keenan, M. (Eds.), Restorative responses to sexual violence (pp.179-191), Routledge. https://doi.org/10.4324/9781315630595-9

McGlynn, C., Westmarland, N. \& Godden, N. (2012). 'I just wanted him to hear me': sexual violence and the possibilities of restorative justice. Journal of law and society, 39(2), 213-240. https://doi.org/10.1111/j.1467-6478.2012.00579.x

Naylor, B. (2010). Effective Justice for Victims of Sexual Assault: Taking up the Debate on Alternative Pathways. UNSW Law Journal 33(3), 664-682.

Pali, B. \& Madsen, K.S. (2011). Dangerous Liaisons? A Feminist and Restorative Approach to Sexual Assault. Temida, 14(1), 49-55. https://doi.org/10.2298/TEM1101049P 
Petrak, J. \& Hedge, B. (2002). The psychological impact of sexual assault. The trauma of sexual assault: Treatment, prevention, and practice. Wiley.

Robson, D. (2018). Help! A problem page for restorative practitioners. Resolution, 62, 11. https://restorativejustice.org.uk/sites/default/files/resources/files/Resolution $\% 20 \% 2362 \% 20$ Spring\%202018.pdf

Sherman, L. W., Strang, H., Mayo-Wilson, E., Woods, D. J., \& Ariel, B. (2015). Are restorative justice conferences effective in reducing repeat offending? Findings from a Campbell systematic review. Journal of Quantitative Criminology, 31(1), 1-24. https://doi.org/10.1007/ s10940-014-9222-9

Sherman, L., \& Strang, H. (2007). Restorative justice: The evidence. Smith Institute.

Strang, H., \& Sherman, L. W. (2003). Repairing the harm: Victims and restorative justice. Utah Law Review, 1, 15-42.

Strang, H., Sherman, L. W., Mayo-Wilson, E., Woods, D., \& Ariel, B. (2013). Restorative justice conferencing (RJC) using face-to-face meetings of offenders and victims: Effects on offender recidivism and victim satisfaction. A systematic review. Campbell Systematic Reviews, 9(1), 1-59. https://doi.org/10.4073/csr.2013.12

Strang, H., Sherman, L., Angel, C. M., Woods, D. J., Bennett, S., Newbury-Birch, D., \& Inkpen, N. (2006). Victim evaluations of face-to-face restorative justice conferences: A quasi-experimental analysis. Journal of Social Issues, 62(2), 281-306. https://doi.org/10.1111/j.15404560.2006.00451.x

Vives-Cases, C., Ruiz-Cantero, M. T., Escribà-Agüir, V., \& Miralles, J. J. (2011). The effect of intimate partner violence and other forms of violence against women on health. Journal of Public Health, 33(1), 15-21. https://doi.org/10.1093/pubmed/fdq101

Zehr, H. (2005). Changing Lenses: A New Focus on Crime and Justice. Herald Press.

Zinsstag, E. (2017). How Appropriate is the Use of Restorative Justice in Cases of Sexual Violence? Scottish Justice Matters, 5(1), 30-31.

\section{A cikkben található online hivatkozások}

URL1: European Commission. Report from the Commission to the European Parliament and the Council. https://eur-lex.europa.eu/legal-content/EN/TXT/PDF/?uri=CELEX:52020DC0188\&from $=\mathrm{EN}$

URL2: Bünügyi Statisztikai Rendszer. Regisztrált büncselekmények száma az elkövetés helye szerint 2018. II. félévtöl. https://bsr.bm.hu/document/details?id=72 


\section{Alkalmazott jogszabályok}

2012. évi C. törvény a Büntető Törvénykönyvről

2006. évi CXXIII. törvény a büntető ügyekben alkalmazható közvetítői tevékenységről

2012. évi II. törvény a szabálysértésekről, a szabálysértési eljárásról és a szabálysértési nyilvántartási rendszerről

\section{A cikk APA szabály szerinti hivatkozása}

Schmidt L. (2021). Helyénvaló-e a helyreállító igazságszolgáltatás alkalmazása a szexuális jellegü büncselekmények esetében? Belügyi Szemle, 69(7), 1115-1131. https://doi.org/10.38146/ BSZ.2021.7.2 